\title{
Mineração
}

\section{An investigation of Acid Rock Drainage (ARD) occurrence in a gold mine located in a southeastern Brazil region}

\author{
Luciana Xavier de Lemos Capanema \\ M. Sc. Metallurgical and Mining Engineering/UFMG \\ E-mail: lucapanema@bol.com.br \\ Virgínia Sampaio Teixeira Ciminelli \\ Metallurgical and Material Engineering Department \\ Universidade Federal de Minas Gerais \\ E-mail: ciminelli@demet.ufmg.br
}

\section{Resumo}

Esse trabalho tem como objetivo avaliar o potencial de geração de Drenagem Ácida de Rocha (ARD) de duas amostras de minério de ouro sulfetado através de três das mais tradicionais técnicas de diagnóstico de ARD: "Standard Acid Base Accounting and Modified Acid Base Accounting", métodos estáticos, e células úmidas, método cinético. As amostras foram submetidas a uma caracterização química e mineralógica que indicou a presença de traços de sulfetos, tais como pirita, arsenopirita e pirrotita e de carbonatos, tais como calcita e dolomita. Considerando os resultados dos ensaios realizados, foi confirmada a necessidade de se utilizarem diversas técnicas para se concluir sobre o potencial de geração de ARD dessas amostras. Enquanto os resultados dos ensaios do "Standard ABA" foram inconclusivos, os resultados de NNP e NP/AP do "Modified ABA" indicaram uma tendência de as amostras TP01 e WP01 serem geradoras de ácido, sendo essa tendência discretamente mais acentuada para WP01. Assim, o ensaio cinético foi conduzido para elucidar os resultados. Os resultados das células úmidas para as amostras TP01 e WP01 indicaram a provável oxidação dos sulfetos resultando na produção de ácido, seguida de neutralização pela alcalinidade gerada pelos carbonatos. Com base nesses resultados, pode ser concluído que, apesar de a amostra WP01 apresentar um potencial de geração de ARD ligeiramente superior a TP01, essas amostras podem estar em diferentes estágios no processo, ou melhor, TP01 deve estar em um estágio de geração de ARD mais avançado que WP01. O papel fundamental dos ensaios cinéticos foi ressaltado pelos resultados.

Palavras-chave: drenagem ácida, testes ABA, células úmidas.

\section{Abstract}

This work is aimed at evaluating the potential of Acid Rock Drainage (ARD) from two Brazilian gold sulfidic ore samples, by means of using three of the most traditional ARD prediction techniques: Standard Acid Base Accounting and Modified Acid Base Accounting, as static methods, and humidity cells, as a kinetic method. Samples were submitted to chemical and mineralogical characterization that indicated the presence of traces of sulfide minerals, such as pyrite, arsenopyrite, pyrrhotite and of carbonates, calcite and dolomite. While the Standard ABA results were inconclusive, the Modified ABA NNP results and NP/ $A P$ ratio suggested a tendency of TP01 and WPO1 being acid generators, this tendency being slightly stronger for sample WP01. So, a kinetic test was conducted to elucidate the results. The humidity cells results for samples TP01 and WPO1 indicated the probable sulfide oxidation to produce acid, subsequently neutralized by alkalinity generated by the carbonates. Based on the results, one can conclude that although sample WP01 has a slightly higher ARD generation potential than TP01, these samples can be at different stages of ARD process, or better, TP01 is at a more advanced stage of $A R D$ production than WP01. The determinant role of the kinetic tests is highlighted by the results.

Keywords: acid mine drainage, ABA tests, humidity cell. 


\section{Introduction}

Predicting the occurrence of acid rock drainage (ARD) is an important challenge to the mining industry. Today, many laboratory static and kinetic tests are available to predict ARD occurrence. White III et al (1999) considered static tests as short term and relatively low cost per sample. Their main objective is to provide an estimate of a mine waste capacity to produce acid and its capacity to neutralize acid. One of the principal disadvantages of static tests is that they measure only the capacities for acid production and consumption, not considering the differences between the respective dissolution rates of these reactions. Another potential error is due to the static test assumption that all acidproducing and acid-consuming minerals will react completely, regardless of the minerals particle-size, morphology or passivation. Kinetic tests are considered long term and expensive per sample. Their objectives are to confirm or reduce uncertainty in static test classification, identify dominant chemical-weathering reactions, and determine acid-generation rates and temporal variation in leachate water quality. This is accomplished by accelerating the natural weathering rates of a mine-waste sample under closely controlled laboratory conditions.

Environmental priorities vary according to the regulatory authorities' understanding of mining and its environmental impact. Ibacache and Thorpe (1997) believe that as much as water quality standards can address control requirements, regulatory authorities will need more insight into of what acid rock drainage is and what reasonable values are necessary for the prevention of environmental damage. As the occurrence of ARD in Brazilian base and precious metal ores is of a relatively new concern, the studies related to this phenomenon are just beginning. Taking this into account, this study aims to evaluate three of the most commonly used ARD prediction methods at a Brazilian mine site. As a case study, two samples from a gold mine will be fully evaluated using a broad sample characterization, two static prediction methods and humidity cells.

\section{Experimental}

The two solid samples of a sulfidic gold ore from a region of Southeastern Brazil were studied in this work. The tailings sample (TP01) and the waste rock sample (WP01) were reduced to the particle size recommended by each prediction method. The methodology adopted for the samples characterization and ARD prediction was presented by Capanema and Ciminelli (2003). The Sobek Acid Base Accounting, here indicated as the Standard ABA (Sobek et al, 1978) and a modified version of this test proposed by Lawrence and Wang (1997) were selected for this study. These static prediction tests were complemented by a kinetic test in humidity cells (ASTM, 1998). A description of these methods was provided in Capanema and Ciminelli (2003). Acidity and alkalinity were determined according to the procedures described by Clesceri et al (1992).

\section{Results and discussion}

\subsection{Samples}

The elemental analyses of the tailings and waste rock indicate the presence of silicon and aluminum as the main constituents followed by iron, calcium, magnesium, potassium, manganese, sodium and titanium. The following trace elements: $\mathrm{As}, \mathrm{Au}, \mathrm{Cr}, \mathrm{Ni}$, $\mathrm{Sr}, \mathrm{Zn}, \mathrm{Zr}, \mathrm{Pb}$ and $\mathrm{V}$ were also detected by X-ray fluorescence analyses. Table 1 presents the content of the most important elements in ARD prediction.

Based on Table 1, and within the analytical error, all the sulfur content in sample WP01 can be considered as sulfide sulfur. Calcium and carbon content indicates that the carbonate content in samples TP01 and WP01 is not sufficient to buffer the potential acid generated. Very high amounts of arsenic are found to be present in these two samples.

As the density and specific surface area values for the two samples are very close, $2.85-2.86 \mathrm{~g} / \mathrm{cm}^{3}$ and $1.27-1.57 \mathrm{~m}^{2} /$ $\mathrm{g}$, a similar overall reactivity can be expected. The samples' size distribution is narrow and very similar; the particle size analyses indicated that $95 \%$ of the particles in the two samples are below $0.15 \mathrm{~mm}$. According to the X-Ray diffraction analyses, the two samples are mainly composed of quartz (ICDD n ${ }^{\circ} 33$ 1161) followed by muscovite (ICDD ${ }^{\circ}$ 07-0042), feldspar/albite (ICDD n ${ }^{\circ} 09$ 0466), while olivine/forsterite (ICDD n ${ }^{\circ}$ 31-0795) and kaolinite (ICDD n ${ }^{\circ}$ 06-0221) are also present in smaller quantities. Textural comments about crystal size, mineral association, sulfides and carbonates liberation, these being the most susceptible minerals to weathering, are summarized in Table 2.

Based on Table 2, sample TP01 presents about $1 \%$ of pyrite, $<1 \%$ of arsenopyrite and rare occurrence of pyrrhotite. The sulfide species content

Table 1 - Selected elemental analyses of the solid samples TP01 and WP01.

\begin{tabular}{c|c|c|c|c|c|c|c|c|c|c}
\hline Sample & $\begin{array}{c}\text { S-total } \\
(\%)\end{array}$ & $\begin{array}{c}\text { S-sulfide } \\
(\%)\end{array}$ & $\mathbf{C}(\%)$ & $\begin{array}{c}\text { As (mg/kg) } \\
(\%)\end{array}$ & $\mathbf{C a}(\%)$ & $F e(\%)$ & $\mathbf{M g}(\%)$ & $\begin{array}{c}\mathbf{N i} \\
(\mathbf{m g} / \mathbf{k g})\end{array}$ & $\begin{array}{c}\mathbf{P b} \\
(\mathbf{m g} / \mathbf{k g})\end{array}$ & $\begin{array}{c}\mathbf{Z n} \\
(\mathbf{m g} / \mathbf{k g})\end{array}$ \\
\hline TP01 & 0.93 & 0.85 & 0.68 & 1688 & 0.11 & 0.11 & 0.53 & 23 & 137 & 133 \\
\hline WP01 & 1.05 & 1.13 & 0.79 & 3137 & 0.39 & 4.1 & 1.6 & 119 & 135 & 233 \\
\hline
\end{tabular}


is confirmed by chemical analyses: about $1 \%$ of pyrite and $0.4 \%$ of arsenopyrite (Table 1). The sulfide species, in general, are liberated. The sample presents about $9 \%$ of carbonates (mainly as calcite and dolomite) and these are, in general, liberated. Based on the calcium content obtained by atomic absorption, the maximum carbonate content in sample TP01 is approximately $4 \%$. This value assumes that all $\mathrm{Ca}$ comes from calcite and all carbon from carbonate, which is not realistic. So, the petrographic analyses have clearly overestimated carbonate content. At first these characteristics suggest that these two samples could generate acid, but the final impact would depend on the neutralizing potential and kinetics. To better investigate these samples, static and kinetic prediction tests were conducted.

\subsection{Static Methods}

Prior to these tests, the paste $\mathrm{pH}$ and the Fizz test were carried out (Table 3) based on the method by Sobek et al (1978).

According to Sobek et al (1978), the paste $\mathrm{pH}$ above 7 (Table 3 ) suggests the presence of reactive carbonate and TP01 paste $\mathrm{pH}$ of 6.9 is inconclusive. The two samples presented no "fizz" rating, which indicates that carbonate content is below the upper limit of $4 \%$ estimated by $\mathrm{Ca}$ and $\mathrm{C}$ content. Therefore, the concentration of the $\mathrm{HCl}$ and $\mathrm{NaOH}$ used were, respectively, 0.10 and $0.098 \mathrm{~N}$. In the Modified ABA, 1.0 N HCl solution is added twice during the test (at time 0 and after $2 \mathrm{~h}$ ). Based on the fizz rating, the recommended values for time 0 and $2 \mathrm{hs}$ are $1.0 \mathrm{~mL}$ (Lawrence and Wang,
1997). The two samples were submitted to Standard ABA test and the results are presented in Table 4. In Table 4, the accuracy of the test analysis was validated by the analysis of reference material. The NP and AP values shown by the waste rock (WP01) and the tailings (TP01) are quite similar, and the NNP as well, being the ARD potential only slightly higher for WP01. Based on the NNP values, approximately $20 \mathrm{~kg} / \mathrm{t}$ $\mathrm{CaCO}_{3}$ equivalent, the samples are included in a "grey" area, though very close to the limit established for acid generation, i.e., $<-20 \mathrm{~kg} / \mathrm{t} \mathrm{CaCO}_{3}$. The uncertainty indicates the necessity of applying other prediction methods to better characterize these samples. Now, the Modified ABA results are presented in Table 5. For this test, $2.00 \mathrm{~g}$ of $100 \%$ $<0.03 \mathrm{~mm}$ sample was required.

Table 2 - Textural comments on a selected sample TP01 (Vieira and Ribeiro, 2001).

\begin{tabular}{|c|c|c|c|c|}
\hline Mineral & $\begin{array}{l}\% \text { Semi- } \\
\text { quantitative }\end{array}$ & Size $(\mathrm{mm})$ & Liberation & Association \\
\hline Pyrite $\mathrm{FeS}_{2}$ & 1 & $<0.02$ to 0.59 & $\begin{array}{l}\text { Frequently, liberated crystals. Less } \\
\text { frequently associated particles. }\end{array}$ & $\begin{array}{l}\text { Principally, muscovite and } \\
\text { quartz. Less frequently, } \\
\text { biotite and magnetite. }\end{array}$ \\
\hline Arsenopyrite FeAsS & $<1$ & $<0.02$ to 0.56 & $\begin{array}{l}\text { The crystals, are in general, } \\
\text { liberated. They are rarely } \\
\text { aggregated. }\end{array}$ & - \\
\hline Pyrrhotite $\mathrm{Fe}_{7} \mathrm{~S}_{8}$ & Rare & 0.49 to 1.24 & Liberated. & - \\
\hline $\begin{array}{l}\text { Carbonate (Dolomite - } \\
\mathrm{CaMg}\left(\mathrm{CO}_{3}\right)_{2} \text { and } \\
\left.\text { Calcite- }-\mathrm{CaCO}_{3}\right)\end{array}$ & 9 & 0.02 to 0.54 & $\begin{array}{l}\text { In general, liberated. Less } \\
\text { frequently, associated to rock } \\
\text { fragments. }\end{array}$ & $\begin{array}{l}\text { Quartz, muscovite and } \\
\text { rarely rutile and } \\
\text { arsenopirite. }\end{array}$ \\
\hline
\end{tabular}

Table 3 - Paste pH and Fizz Test results.

\begin{tabular}{c|c|c}
\hline Sample & Paste pH & Fizz Test \\
\hline TP01 & 6.87 & None \\
\hline WP01 & 8.22 & None \\
\hline NBM-1 & - & Slight \\
\hline
\end{tabular}

Table 4 - Standard ABA results for TP01 and WP01 samples.

\begin{tabular}{lc|c|c|c|c|c}
\hline & \multicolumn{2}{|c|}{ Samples } & \multicolumn{2}{c}{ Reference Material (NBM-1) } \\
\hline & TP01 & WP01 & $\begin{array}{c}\text { Certified } \\
\text { Value }\end{array}$ & $\begin{array}{c}\text { Analytical } \\
\text { Result }\end{array}$ & $\begin{array}{c}\text { Difference } \\
(\%)\end{array}$ \\
\hline $\mathrm{NP}(\mathrm{tCaCO} / 1000 \mathrm{t})$ & Mean & 11.7 & 13.6 & 52.0 & 53.0 & 2 \\
& Std.Dev. & 0.4 & 0.5 & - & 1.0 & - \\
\hline $\mathrm{AP}(\mathrm{tCaCO} / 1000 \mathrm{t})$ & Mean & 28.9 & 32.8 & 0.298 & 0.29 & 2.7 \\
\hline $\mathrm{NNP}(\mathrm{tCaCO} / 1000 \mathrm{t})$ & Mean & -17.2 & -19.3 & 42.0 & 44.0 & 4.7 \\
\hline
\end{tabular}


From table 5, one observes that regardless of the fact that the waste rock sample (WP01) presented significantly higher NP measurements than the tailings sample (TP01), the resultant NNP indicated WP01 as the most acid generator. The higher NP for WPO1 values are expected by the calcium, magnesium and carbon concentrations presented in Table 1. Comparing the NP values obtained by the Standard and the Modified ABA, one can observe that the first method presented NP results significantly higher (five times (TP01) and twice (WP01)) than the second, thus indicating the dissolution of noncarbonate constituents during the hot acid leaching adopted by the Std. ABA. Comparing the AP determination, the results presented a difference of about » $10 \%$ between the two static methods, which is consistent with the sulfide and total sulfur analyses (Table 1). The NNPs obtained by the Standard ABA are not conclusive while the NNPs obtained by the Modified ABA indicate that the samples could be acid generators. A zone of uncertainty may exist between NP/AP ratios of 1 and 3. The NP/AP ratio for both samples confirms the tendency of being acid generators. The samples were submitted to humidity cell tests during a period of 30 weeks for better evaluation of their behavior.

\subsection{Kinetic Methods}

Temporal changes in leachate chemistry and evidence for the onset of ARD generation can be more easily discerned by plotting values against time. Rates of acid, alkaline or sulfate generation, and of metal release can be determined from the plotted data. The rate of carbonate-based NP consumption is represented here by calcium concentration. For this test, the humidity cells were filled with $1.0 \mathrm{~kg}$ of sample $100 \%<6.3 \mathrm{~mm}$. The composition of the leachate during the humidity cells operation is presented in Table 6 . Chromium and vanadium were also analyzed but their concentration was under the detection limit of the adopted method.

Table 5 - Modified ABA Results.

\begin{tabular}{c|c|c|c}
\hline & & TP01 & WP01 \\
\hline \multirow{2}{*}{$\mathrm{NP}(\mathrm{tCaCO} / 1000 \mathrm{t})$} & Mean & 2.8 & 6.6 \\
\cline { 2 - 4 } & Std.Deviation & 1.4 & 2.5 \\
\hline $\mathrm{AP}\left(\mathrm{tCaCO}_{3} / 1000 \mathrm{t}\right)$ & Mean & 26.6 & 36.2 \\
\hline $\mathrm{NNP}\left(\mathrm{tCaCO}_{3} / 1000 \mathrm{t}\right)$ & Mean & -23.9 & -28.6 \\
\hline \multirow{2}{*}{$\mathrm{NP} / \mathrm{AP}$} & Mean & 0.11 & 0.19 \\
\cline { 2 - 4 } & Std. Deviation & 0.05 & 0.07 \\
\hline
\end{tabular}

Table 6 - Humidity Cells TP01 and WP01.

\begin{tabular}{|c|c|c|c|c|c|c|c|c|c|c|}
\hline \multirow{2}{*}{ Week } & \multicolumn{2}{|c|}{ Conductivity( $\mu \mathrm{S})$} & \multicolumn{2}{|c|}{$\mathrm{Fe}(\mathrm{mg} / \mathrm{L})$} & \multicolumn{2}{|c|}{$\mathrm{Ni}(\mathrm{mg} / \mathrm{L})$} & \multicolumn{2}{|c|}{ Zn (mg/L) } & \multicolumn{2}{|c|}{ As (mg/L) } \\
\hline & TP01 & WP01 & TP01 & WP01 & TP01 & WP01 & TP01 & WP01 & TP01 & WP01 \\
\hline 0 & 309 & 2150 & 0.2 & 1.7 & 0.7 & 7.6 & 3.4 & 10.6 & $<1$ & $<1$ \\
\hline 1 & 2520 & 1129 & 0.2 & $<0.1$ & 2.5 & 3.8 & 0.8 & 2.0 & 1.1 & $<1$ \\
\hline 4 & 1896 & 213 & 4.0 & 0.2 & 8.8 & 0.6 & 21.4 & 3.1 & 4.1 & $<1$ \\
\hline 6 & 1295 & 379 & 20.5 & 0.2 & 7.2 & 0.6 & 19.8 & 0.7 & 6.8 & $<1$ \\
\hline 8 & 764 & 457 & 36.3 & $<0.1$ & * & 0.7 & * & 0.6 & 1.1 & $<1$ \\
\hline 10 & 406 & 449 & 20.3 & 0.4 & 1.2 & 0.7 & 6.0 & 0.5 & 1.6 & $<1$ \\
\hline 14 & 1101 & 424 & 14.7 & $<0.1$ & 4.5 & 0.5 & 8.4 & $<0.01$ & 12.9 & $<1$ \\
\hline 16 & 851 & * & 109.8 & $<0.1$ & 3.9 & $<0.1$ & 11.4 & 0.03 & 8.0 & $<1$ \\
\hline 18 & 1108 & 349 & 180.0 & 0.6 & 4.6 & 0.3 & 16.2 & 0.5 & 6.1 & $<1$ \\
\hline 20 & 1291 & 431 & * & 0.4 & 6.9 & 0.5 & 12.8 & 0.6 & 4.4 & $<1$ \\
\hline 22 & 1128 & 329 & 22.0 & 0.3 & 4.1 & 0.7 & 1.1 & 0.3 & $<1$ & $<1$ \\
\hline 24 & 1268 & 327 & $<0.1$ & 0.1 & $<0.1$ & 0.6 & 10.6 & 0.6 & $<1$ & $<1$ \\
\hline 27 & 1508 & 365 & 336.8 & 1.0 & 3.2 & 0.5 & 10.4 & 0.5 & 3.1 & $<1$ \\
\hline 29 & 1461 & 340 & 334.0 & 0.2 & 3.0 & 0.5 & 9.2 & 0.3 & $<1$ & $<1$ \\
\hline 30 & 1497 & 323 & 279.9 & $<0.1$ & 2.4 & 0.2 & 8.4 & 0.5 & $<1$ & $<1$ \\
\hline \multicolumn{3}{|c|}{$\begin{array}{c}\text { COPAM no 10, } 1986 \text { (water for } \\
\text { domestic use) }\end{array}$} & \multicolumn{2}{|c|}{6.0} & \multicolumn{2}{|c|}{0.025} & \multicolumn{2}{|c|}{6.0} & \multicolumn{2}{|c|}{0.05} \\
\hline
\end{tabular}


Considering the analytical results presented in Table 6, sample TP01 leachate in general presents the highest conductivity values, highest metal dissolution and As detections in significant concentrations. The increase in specific conductivity presented by sample TP01 indicates the presence of ionic species, confirmed by the elemental determination, this being a strong indication of ARD occurrence. The acceptable concentrations in drinking water for some chemical elements expressed in "Portaria No.1.469", by the Brazilian Ministry of Healthy of October, 2001, are: As - $0.01 \mathrm{mg} / \mathrm{L}, \mathrm{Fe}-0.3 \mathrm{mg} / \mathrm{L}, \mathrm{Ni}-0.025 \mathrm{mg} / \mathrm{L}$ and $\mathrm{Zn}-5.0 \mathrm{mg} / \mathrm{L}$. Based on these legal limits, sample TP01 presented As, Fe, Ni and Zn measurements over the acceptable values.

The Eh-pH diagram for samples TP01 and WP01 is presented in Figure 1. Sample TP01 generated more oxidative and acidic conditions, as $\mathrm{pH}$ was lower than 4 and Eh higher than $450 \mathrm{mV}$. Conversely, WP01 presented Eh near $450 \mathrm{mV}$ and $\mathrm{pH}$ near neutral. At the beginning of the test, sample TP01 presented Eh of $483 \mathrm{mV}$ and $\mathrm{pH}$ of 6.0, while the final leachate determinations were Eh of 600 $\mathrm{mV}$ and $\mathrm{pH}$ of 3.3. As $\mathrm{pH}$ decreases and Eh increases, the role of the Ac. Ferroxidans can become significant and highly acid generating conditions will be created, thus indicating ARD occurrence. On the other hand, sample WP01 presented a decrease in Eh measurements from an initial value of $318 \mathrm{mV}$ to a final value of $283 \mathrm{mV}$ and a slight increase in $\mathrm{pH}$ measurements from 4.5 to 6.1. Redox values $<400 \mathrm{mV}$ might be considered as relatively low and $\mathrm{pH}$ in a range of 5-6.5 means that sample is not generating significant acid or the system is dominated by alkalinity from calcareous material.

The variation of sulfate sulfur and Ca concentrations is presented in Figure 2. An increase in sulfate concentration is another ARD indicator; the two samples evaluated presented a decrease in sulfate concentration followed by stabilization. Considering Figure 2 (sample TP01) the sulfur concentration seems to be higher than the $\mathrm{Ca}$ concentration during the test, but the equality of the S-total and $\mathrm{S}_{-} \mathrm{SO}_{4}$ (not shown here) indicates the end of the sulfur oxidation. In the case of sample WP01, the Stotal, $\mathrm{S}-\mathrm{SO}_{4}$ release rates seem to be only slightly higher than the $\mathrm{Ca}$ release rate, thus meaning that carbonates may be buffering the acid production. Based on this fact, the test was then ended.

Figure 3 presents the acidity and alkalinity determinations for sample WP01 leachate during the entire test. The WP01 leachate alkalinity was, in general, higher than the acidity, which indicates that the sample should be considered, at least, as neutral. Lawrence and Marchant (1991) recommended caution in comparing the acidity and alkalinity releases due to the differences in the kinetics and equilibria of the acid generating, acid consuming, and alkalinity generating reactions under laboratory and field conditions. Sample TP01 alkalinity and acidity could not

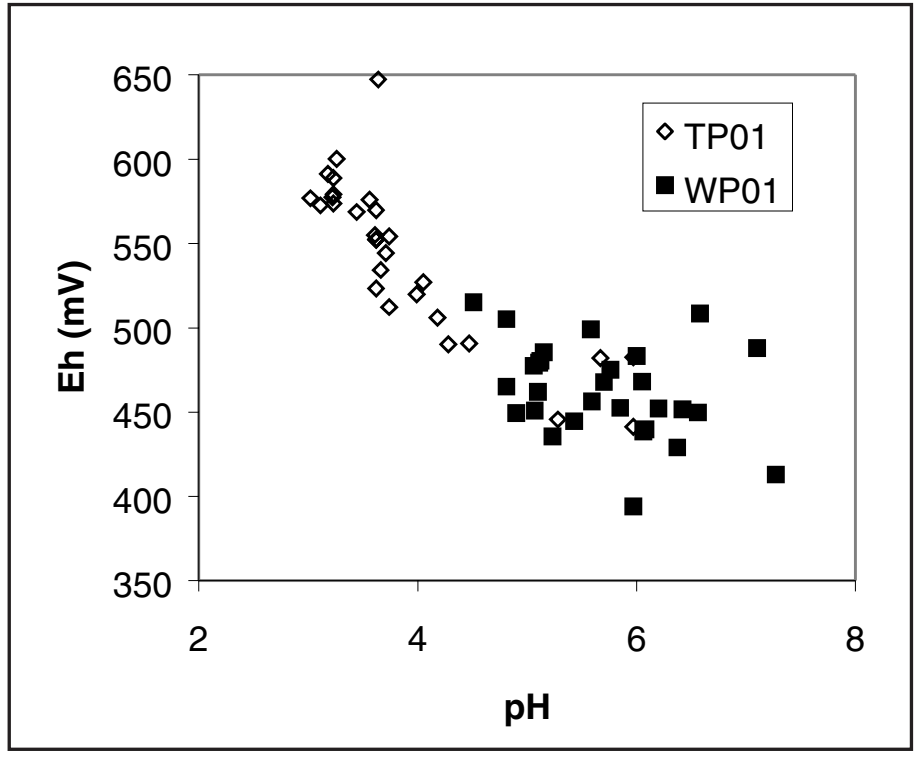

Figure 1- Eh-pH diagram for samples TP01 and WP01.

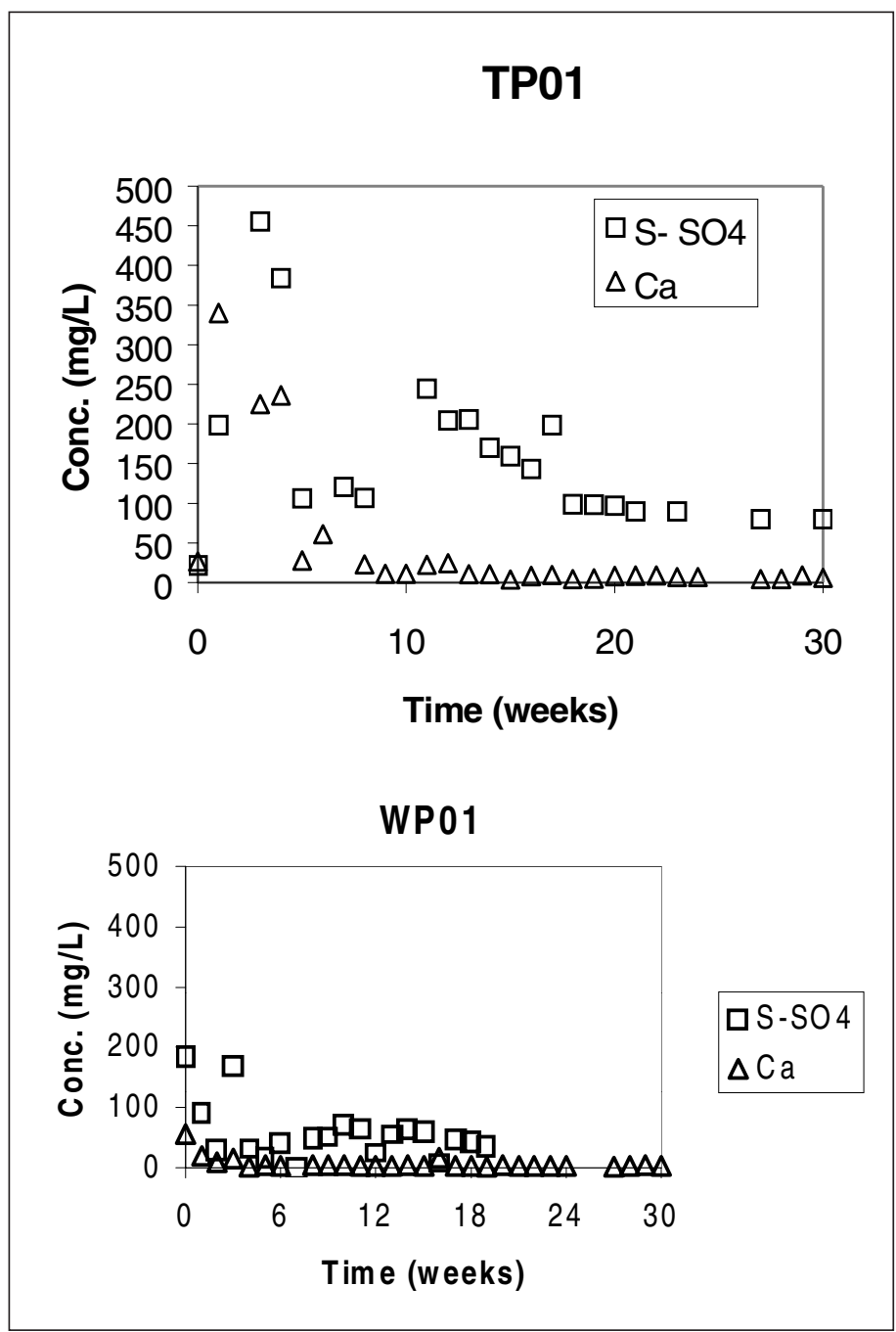

Figure 2 - Variation of sulfate and calcium concentrations as a function of time. 
be measured using the methods adopted in this work due to the precipitation of an amorphous phase that occurred during the analyses.

Summarizing, for sample TP01, the leachate conductivity can be considered high, the sulfate concentration high, the acidity high and alkalinity low, which indicates the probable pyrite oxidation. For sample WP01, the leachate acidity and alkalinity can be considered low, the conductivity decreased during the test and the sulfate concentration can be considered significant, which indicate the pyrite oxidation to produce acid, subsequently neutralized by alkalinity and the sample's tendency to become inert. Considering the static tests results, sample WP01 seems to have a higher acid generation potential than TP01. As the paste $\mathrm{pH}$ indicated that TP01 had a prior acidity, it is possible that this sample was at a more advanced stage of ARD generation than WP01.

\section{Conclusions}

The X-Ray diffraction patterns of samples TP01 and WP01 show quartz as their main constituent followed by muscovite, feldspar and in lesser proportions, olivine and kaolinite. Textural observations about the tailings sample (TP01) showed the presence of sulfide minerals, such as pyrite, arsenopyrite and pyrrhotite in low concentrations and carbonates, in the form of calcite and dolomite. Considering the overall results, the necessity of using many techniques to compose a conclusion about the ARD potential of this group of samples is clearly seen. Considering the kinetic test results, sample TP01 seems to generate more oxidative conditions than WP01. When the $\mathrm{S}-\mathrm{SO}_{4}$ and $\mathrm{Ca}$ release rates are considered, the two samples presented a very similar tendency, decreasing rates meaning the end of sulfur oxidation and a probable buffer action of the carbonates. Sample TP01 presented higher metal dissolution rates than sample WP01 and consequently higher conductivity, due probably to its higher oxidative conditions- and its higher specific surface area. Summarizing, the

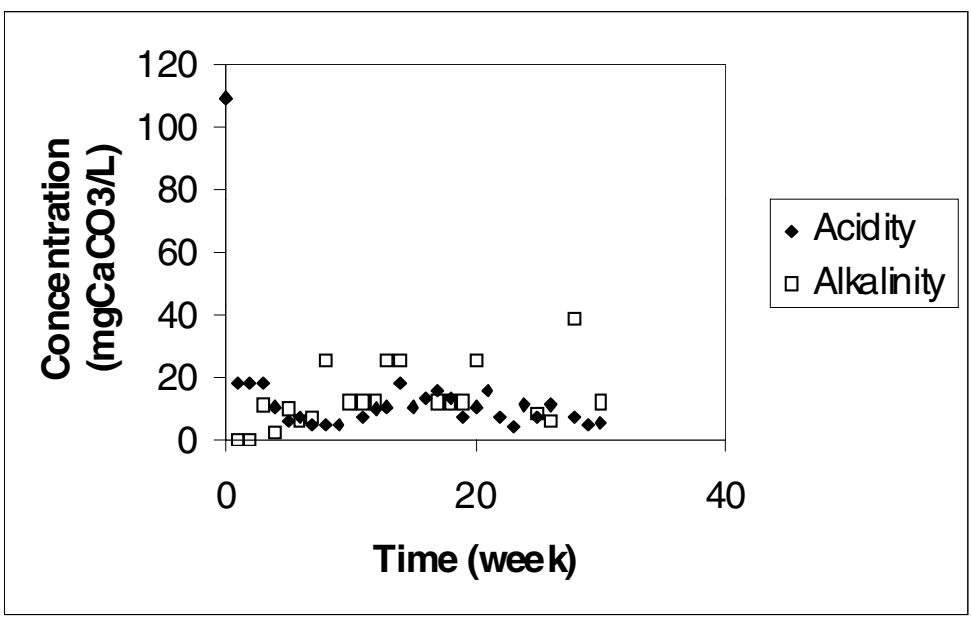

Figure 3 - WP01 leachate acidity and alkalinity during the test.

humidity cells results for samples TP01 and WP01 indicate the probable sulfide oxidation to produce acid, subsequently neutralized by alkalinity generated by the carbonates. Based on these results, one concludes that although sample WP01 has a slightly higher ARD generation potential than TP01, these samples can be at different stages of ARD process, or better, TP01 is at a more advanced stage of ARD production than WP01. The determinant role of kinetics is highlighted by the results.

\section{Acknowledgements}

The authors would like to acknowledge the support of CNPq and Pronex. The support of Companhia Vale do Rio Doce-CVRD, especially of Beatriz Vieira and Geysa Pereira, in the analyses of the samples, is gratefully acknowledged. The project is part of the Millennium Science Initiative: Water-a mineral approach.

\section{References}

ASTM. D 5744-96, Standard test method for accelerated weathering of solid materials using a modified humidity cell, 1998, p.113.

CAPANEMA, L.X.L., CIMINELLI, V.S.T. Acid rock drainage (ARD) potential of a Brazilian gold ore. In: INTERNATIONAL CONFERENCE ON ACID ROCK DRAINAGE, 6, 2003, Cairns, Australia, 12-18 July 2003, AusIMM, Carlton South, VIC, Australia, Proceedings...(cd-rom), 2003, p. 973-982.
CLESCERI, L. S., GREENBERG, A. E., TRUSSELL, R. R.Standard methods - For the examination of water and wastewater. $7^{\text {th }}$ Edition. Washington DC: American Public Health Association editors. 1992. 2-30-2-39.

IBACACHE, A.M.B., THORPE, M.B. Acid rock drainage and the Latin America regulatory regime. In: INTERNATIONAL CONFERENCE ON ACID ROCK DRAINAGE, 4, 1997. Vancouver, Proceedings... 1997, v. 4, p. 1919-1934.

LAWRENCE, R.W., WANG, Y.Determination of neutralization potential in the prediction of acid rock drainage. In: INTERNATIONAL CONFERENCE ON ACID ROCK DRAINAGE, 4, 1997. Vancouver. Proceedings... 1997, v. 1, p. 451-454.

LAWRENCE, R. W., MARCHANT, P.M. Acid rock drainage prediction manual. MEND/ NEDEM Report 1.16.1b. Ottawa: Canadian Centre for Mineral and Energy Technology. 1991.

SOBEK, A. A., SCHULLER, W.A., FREEMAN, J.R., SMITH, R.M. Field and laboratory methods applicable to overburdens and minesoils. EPA-600/2-78054. Ohio: U.S. Environmental Protection Agency, Cincinnati. 1978.

VIEIRA, M.B.H., RIBEIRO, L.(technical report). Avaliação da aplicação de métodos de diagnóstico de drenagem ácida de rochas/ minérios brasileiros. Santa Luzia: Companhia Vale do Rio Doce, Minas Gerais. 2001

WHITE III, W.W., LAPAKKO, K. A., COX, R.L. The environmental geochemistry of mineral deposits, Part A: Theory and background. In: PLUMLEE, G.S., LOGSDON, M. (ed.). Society of Economic Geologists Reviews in Economic Geology, v. 7A, p. 325-338, 1999.

\section{Artigo recebido em 27/05/2003 e aprovado em 11/09/2003.}

